\title{
Literature Review : Penerapan Teknik Pernafasan Buteyko Terhadap Penurunan Frekuensi Kekambuhan Asma Pada Pasien Asma Bronkhial
}

\author{
Pratika Oktania Salsabila ${ }^{1} *$, Firman Faradisi ${ }^{2}$ \\ 1,2Program Studi Diploma Tiga Keperawatan, Fakultas Ilmu Kesehatan Universitas \\ Muhammadiyah Pekajangan Pekalongan \\ *email: pratikasalsabila3@gmail.com
}

\begin{abstract}
One of the non-pharmacological therapies to reduce the frequency of asthma recurrence is the Buteyko breathing technique. The study aimed to describe the application of the Buteyko breating technique in asthmatic patients. The study applied Literature Review design. Three articles were obtained from google scolar website, with the keywords "Bronchial Asthma," "Asthma Recurrence," and "Buteyko Breathing Technique". All these three articles were fulltext articles, published in 2014-2021. The result of the Literature Review of the two articles, based on the average value bevore the intervention was 2,74 and after the intervention was 1,66 and one of the articles did not explain the avarge value. The study approved that Buteyko Breathing Technique can be an alternative intervention to reduce the frequency of asthmatic patients. Furthermore, healthcare providers were suggest to educate their patients to do so.
\end{abstract}

Keywords: Asthma Recurrence, Asthmatic Patient, Buteyko Breathing Technique

\begin{abstract}
Abstrak
Salah satu terapi non farmakologis untuk menurunkan frekuensi kekambuhan Asma adalah teknik pernafasan Buteyko. Penelitian ini bertujuan untuk menggambarkan penerapan teknik pernafasan Buteyko pada pasien Asma berdasarkan Literatur Review. Desain Karya Tulis Ilmiah berupa Literatur Review dengan jumlah artikel tiga yang diambil dari laman jurnal google scolar dengan kata kunci "Asma Bronkhial," "Kekambuhan Asma," dan "Teknik Pernafasan Buteyko" berupa artikel fulltex, terbit tahun 2014-2021. Hasil Literatur Review dari kedua artikel berdasarkan nilai rata-rata sebelum intervensi yaitu 2,74 dan sesudah intervensi menjadi 1,66 dan salah satu artikel tidak menjelaskan nilai rata-rata. Kesimpulannya adalah teknik pernafasan Buteyko dapat menurunkan frekuensi kekambuhan asma pada pasien asma. Saran bagi tenaga kesehatan hendaknya mengedukasi tentang teknik pernafasan Buteyko sebagai alternatif untuk menurunkan frekuensi kekambuhan asma pada pasien asma.
\end{abstract}

Kata kunci: Asma Bronkhial, Kekambuhan Asma, dan Teknik Pernafasan Buteyko

\section{Pendahuluan}

Asma adalah peradangan pada jalan nafas yang mengalami penyempitan dikarakteristikan dengan hiperresponsif, edema mukosa, dan produksi mukus yang dapat menimbulkan gejala sesak nafas, mengi, dan batuk jika sputum tidak dapat keluar (Smeltzer, 2017)[10]. Penyakit inflamasi kronik saluran nafas dimana banyak sel berperan terutama sel mast, eosinofil, limfosit $T$, makrofag, neutrofil dan sel epitel. Proses inflamasi dapat menyebabkan wheezing berulang, dada terasa penuh (chest tightness), sesak nafas dan batuk terutama malam atau menjelang pagi (Maranatha 2010 diambil dari Bachri, 2018)[1]. Gejala asma sangat bervariasi terdiri dari dipsnea, 


\section{Prosiding Seminar Nasional Kesehatan Lembaga Penelitian dan Pengabdian Masyarakat Universitas Muhammadiyah Pekajangan Pekalongan}

batuk dan mengi (Somantri 2012 diambil dari Bachri, 2018)[1]. Gejala asma tersebut disebabkan karena peradangan pada jaringan sekitar selaput lendir dan terjadi penyempitan pada saluran nafas (Smeltzer, 2017)[10]. Asma bronkhial adalah penyempitan bronkus atau saluran nafas yang bersifat reversibel karena bronkus yang hiperaktif hal ini terjadi karena bronkus mengalami kontaminasi dengan alergen (Rab,2017)[8].

Prevalensi Asma menurut data laporan World Health Organization (WHO, 2016) sekitar 235 juta dengan angka kematian lebih dari 80\% di negara-negara berkembang. Data prevalensi asma di indonesia mencapai 57,5\% (Riskesdas 2018 diambil dari Setiawan \& Widyastuti, 2019)[11]. Angka kejadian asma di provinsi jawa tengah berjumlah 113.028 kasus pada tahun 2013 dan jumlah penderita asma tertinggi berada di kota surakarta dengan jumlah kasus 10.393 (Dinkes Jawa Tengah 2013 diambil dari Setiawan \& Widyastuti, 2019)[11].

Asma yang sering kambuh akan berakibat fatal jika tidak ditangani dengan benar dan segera maka dapat mengancam kesehatan. Selain itu, dampak negatif dari asma yang tidak cepat ditangani maka dapat terjadi penurunan produktivitas, penurunan kualitas hidup, peningkatan biaya kesehatan dan resiko perawatan dirumah sakit bahkan mengancam kematian (Muchid dkk 2007 diambil dari Maskhanah dkk, 2019)[6]. Penderita asma perlu menjalani terapi tidak hanya dengan pemberian terapi farmakologis tetapi juga menggunakan terapi non farmakologis yaitu dengan mengontrol gejala asma dengan menghindari alergen yang mengakibatkan kekambuhan asma. Salah satu metode yang dikembangkan untuk memperbaiki cara bernafas pada penderita asma adalah teknik olah nafas yaitu dengan teknik pernafasan buteyko (Adha 2013 diambil dari Bachri, 2018)[1].

Teknik pernafasan buteyko merupakan sebuah metode mengatur pola nafas yang dilakukan secara sederhana sebagai manajemen penatalaksanaan asma dengan cara bernafas melalui hidung tanpa menggunakan mulut yang bertujuan untuk mengurangi kerja pernafasan sehingga sesak nafas berkurang dengan prinsip latihan nafas dangkal (Adha 2013 diambil dari Bachri, 2018)[1]. Teknik pernafasan buteyko diciptakan oleh Prof. Dr. Konstantin Buteko asal Rusia yang menjelaskan bahwa teknik pernafasan ini dapat mengurangi hiperventilasi dan bronkopasme atau penyempitan saluran pernafasan sehingga kekambuhan asma dapat diminimalisir. Maskhanah, Noorhidayah, Firdaus dan Rivan (2019)[6] mengatakan bahwa Teknik pernafasan buteyko memiliki beberapa prinsip yang harus dilakukan meliputi nose clearing exercise (latihan pembersihan hidung), menghitung denyut nadi selama satu menit, relaxed breathing (pernafasan relaksasi), control pause (mengontrol jeda nafas), dan reduce breathing (menurunkan aliran pernafasan).

Penelitian mengenai teknik pernafasan buteyko terhadap frekuensi kekambuhan asma yang diteliti oleh Baroroh. I., Hermansyah, Septiyanti (2014)[2] dalam penelitian ini dari 53 responden yang mengalami kekambuhan asma diambil 30 responden dan kemudian diukur frekuensi rata-rata kekambuhannya selama 1 bulan terakhir yaitu 3,40 (95\% CI: 2,91-3,89) ditunjukan hasil penelitian dengan tabel distribusi frekuensi kekambuhan asma sebelum diberikan teknik pernafasan Buyteko adalah 3,40 dan ratarata frekuensi sesudah diberikan teknik pernafasan Buyteko adalah 2,07 (1,62-2,52). 


\section{Prosiding Seminar Nasional Kesehatan 2021 Lembaga Penelitian dan Pengabdian Masyarakat Universitas Muhammadiyah Pekajangan Pekalongan}

Berdasarkan hasil uji statistik pengaruh teknik pernafasan buteyko terhadap penurunan frekuensi kekambuhan asma pada penderita asma di wilayah Kerja Puskesmas Kampung Delima menunjukan nilai $p=0,000<$ a $5 \%$ (one tail) artinya ada penurunan rata-rata frekuensi kekambuhan asma sesudah dilakukan teknik pernafasan buteyko dibandingkan sebelum diberikan terapi dengan teknik pernafasan buteyko. Berdasarkan hasil penelitian ini dapat disimpulkan bahwa teknik pernafasan buteyko berpengaruh terhadap penurunan frekuensi kekambuhan asma.

Dari uraian di atas menjelaskan bahwa penerapan teknik pernafasan buteyko dapat berpengaruh terhadap penurunan frekuensi kekambuhan asma. Pernafasan Buteyko adalah teknik pernafasan yang dilakukan secara sederhana. Oleh karena itu, penulis tertarik untuk melakukan Literature Review dengan judul "Penerapan Teknik Pernafasan Buteyko Terhadap Penurunan Frekuensi Kekambuhan Asma Pada Pasien Asma Bronkhial."

\section{Literature Review}

Asma adalah peradangan pada jalan nafas yang mengalami penyempitan dikarakteristikan dengan hiperresponsif, edema mukosa, dan produksi mukus yang dapat menimbulkan gejala sesak nafas, mengi, dan batuk jika sputum tidak dapat keluar (Smeltzer, 2017)[10]. Penderita asma perlu menjalani terapi tidak hanya dengan pemberian terapi farmakologis tetapi juga menggunakan terapi non farmakologis yaitu dengan mengontrol gejala asma dengan menghindari alergen yang mengakibatkan kekambuhan asma. Salah satu metode yang dikembangkan untuk memperbaiki cara bernafas pada penderita asma adalah teknik olah nafas yaitu dengan teknik pernafasan buteyko (Adha 2013 diambil dari Bachri, 2018)[1].

Teknik pernafasan buteyko merupakan sebuah metode mengatur pola nafas yang dilakukan secara sederhana sebagai manajemen penatalaksanaan asma dengan cara bernafas melalui hidung tanpa menggunakan mulut yang bertujuan untuk mengurangi kerja pernafasan sehingga sesak nafas berkurang dengan prinsip latihan nafas dangkal (Adha 2013 diambil dari Bachri, 2018)[1]. Teknik pernafasan buteyko diciptakan oleh Prof. Dr. Konstantin Buteko asal Rusia yang menjelaskan bahwa teknik pernafasan ini dapat mengurangi hiperventilasi dan bronkopasme atau penyempitan saluran pernafasan sehingga kekambuhan asma dapat diminimalisir. Maskhanah, Noorhidayah, Firdaus dan Rivan (2019) mengatakan bahwa Teknik pernafasan buteyko memiliki beberapa prinsip yang harus dilakukan meliputi nose clearing exercise (latihan pembersihan hidung), menghitung denyut nadi selama satu menit, relaxed breathing (pernafasan relaksasi), control pause (mengontrol jeda nafas), dan reduce breathing (menurunkan aliran pernafasan).

\section{Metode}

Karya tulis ilmiah ini menggunakan rancangan Literature Review. Subjek karya tulis ilmiah adalah hasil penelitian yang sudah dipublikasikan sejumlah 3 (tiga) penelitian dengan topik yang sama yaitu teknik pernafasan buteyko diberikan pada pasien asma dan dilakukan terutama pada intervensi dan respondennya. Kriteria inklusi dalam Karya Tulis Ilmiah ini yaitu 3 artikel ilmiah dengan topik yang sama, artikel ilmiah dengan tahun terbit 10 tahun terakhir. Sedangkan kriteria ekslusinya yaitu 


\section{Prosiding Seminar Nasional Kesehatan Lembaga Penelitian dan Pengabdian Masyarakat Universitas Muhammadiyah Pekajangan Pekalongan}

artikel ilmiah dengan topik yang tidak sama atau berbeda dan artikel ilmiah dengan tahun terbit lebih dari 10 tahun terakhir. Metode pengumpulan data karya tulis ilmiah dilakukan dengan mencari publikasi penelitian dengan topik tentang "pengaruh teknik pernafasan buteyko terhadap penururunan frekuensi kekambuhan asma pada pasien asma" di laman web google scholar dengan kata kunci pernafasan buteyko, kekambuhan asma, dan asma bronkhial kemudian diseleksi dan dipaparkan struktur penulisan publikasi tersebut dan dilakukan analisis. Dari hasil penelusuran tersebut ditemukan 4 artikel ilmiah yang sesuai dengan topik karya tulis ilmiah. Selanjutnya penulis akan menganalisis 4 (empat) artikel ilmiah tersebut dan kemudian penulis akan memilih 3 (tiga) artikel ilmiah yang metodologinya sama atau hampir sama dan dari ketiga artikel tersebut datanya berupa numerik semua atau kategorik semua.

\section{Hasil dan Pembahasan}

\section{Hasil}

Hasil Literatur Review dari 3 (tiga) artikel yang menampilkan karakteristik hanya terdapat pada artikel ke 2 berdasarkan penelitian oleh Maskhanah, dkk (2019)[6]. Karakteristik jenis kelamin, usia, dan pendidikan pada artikel ke 2 dengan jumlah 8 responden dijelaskan pada tabel 4.1.1.

Tabel 4.1.1. Distribusi frekuensi responden berdasarkan jenis kelamin, usia, dan pendidikan $(n=8)$

\begin{tabular}{lcccccc}
\hline Karakteristik & \multicolumn{2}{c}{ Peneliti 1 } & \multicolumn{2}{c}{ Peneliti 2 } & \multicolumn{2}{c}{ Peneliti 3 } \\
\cline { 2 - 7 } & F & $\%$ & F & $\%$ & F & $\%$ \\
\hline Jenis kelamin & - & - & 5 & 62,1 & - & - \\
Laki-laki & - & - & 3 & 37,5 & - & - \\
Perempuan & - & - & 1 & 12,5 & - & - \\
Usia & - & - & 2 & 25 & - & - \\
$20-25$ tahun & - & - & 5 & 62,5 & - & - \\
$26-45$ tahun & - & - & 1 & 12,5 & - & - \\
$45-65$ tahun & - & - & 4 & 50 & - & - \\
Pendidikan & - & - & 2 & 25 & - & - \\
SD & - & - & 1 & 12,5 & - & - \\
SMP & & & & & & \\
SMA & - & & & & & \\
Pendidikan tinggi & & - & & & & \\
\end{tabular}

Berdasarkan tabel 4.1.1 disebutkan bahwa pada penelitian 1 dan penelitian 3 tidak terdapat distribusi frekuensi karakteristik responden berdasarkan jenis kelamin, usia, dan pendidikan. Sedangkan pada penelitian 2 terdapat karakteristik jenis kelamin, usia, dan pendidikan.

4.1.2. Distribusi frekuensi kekambuhan asma sebelum dan sesudah dilakukan intervensi 


\section{Prosiding Seminar Nasional Kesehatan Lembaga Penelitian dan Pengabdian Masyarakat Universitas Muhammadiyah Pekajangan Pekalongan}

Ketiga artikel yang telah direview menunjukan hasil nilai rata-rata frekuensi kekambuhan asma sebelum dan sesudah dilakukan intervensi dapat dilihat pada tabel 4.1.2.

Tabel 4.1.2. Distribusi frekuensi kekambuhan asma sebelum dan sesudah dilakukan intervensi

\begin{tabular}{lcc}
\hline \multicolumn{1}{c}{ Peneliti } & \multicolumn{2}{c}{ Nilai Rata-rata } \\
\cline { 2 - 4 } & Sebelum & Sesudah \\
\hline Peneliti 1 $(n=30)$ & 3,40 & 2,07 \\
Peneliti 2 $(n=8)$ & - & - \\
Peneliti 3 $(n=12)$ & 2,08 & 1,25 \\
\hline Jumlah & 2,74 & 1,66 \\
\hline
\end{tabular}

Berdasarkan tabel 4.1.2 artikel yang didapatkan hanya terdapat dua artikel yang memaparkan hasil rata-rata dan terdapat satu artikel yang tidak memaparkan hasil rata-rata. Pada artikel pertama menjelaskan sebelum diberikan teknik pernafasan Buteyko yaitu dengan nilai rata-rata 3,40 dan sesudah dilakukan teknik pernafasan Buteyko menjadi 2,07. Artikel ketiga menjelaskan sebelum diberikan teknik pernafasan Buteyko dengan niali rata-rata 2,08 menjadi 1,25. Sedangkan artikel yang kedua tidak dijumpai hasil rata-rata akan tetapi disini terdapat pre test $\&$ post test dengan nilai rata-rata yaitu 2,875. Hasil distribusi frekuensi kekambuhan asma dengan jumlah dua artikel sebelum diberikan teknik pernafasan Buteyko yaitu 2,74 dan sesudah dilakukan teknik pernafasan Buteyko menjadi 1,66 dapat disimpulkan bahwa dari kedua artikel yang telah direview dan dilihat dari nilai rata-rata (mean) terdapat penurunan frekuensi kekambuhan Asma.

\section{Pembahasan}

Pada ketiga artikel tersebut ditemukan persamaan yang pertama yaitu sebagian besar penderita asma akan mengalami kekambuhan. Menurut Wahyuni (2012) diambil dari Baroroh (2014)[2] faktor resiko yang berpengaruh terhadap kekambuhan asma dapat berupa faktor cuaca, asap rokok, gangguan emosi, faktor infeksi saluran pernafasan dan faktor olahraga. Adanya kekambuhan ini maka perlu adanya terapi modalitas yang dapat menurunkan kekambuhan, dalam penelitian ini menggunakan pernafasan Buteyko.

Berdasarkan ketiga artikel penelitian tersebut didapatkan persamaan yang kedua yaitu menggunakan terapi pernafasan buteyko karena sama-sama dapat mempengaruhi penurunan frekuensi kekambuhan asma. Hal ini sejalan dengan penelitian Yoana (2009) diambil dari Baroroh, dkk (2014), tentang efektivitas teknik pernafasan buteyko terhadap penurunan tingkat kekambuhan asma pada penderita asma yang menunjukan bahwa teknik pernafasan buteyko efektif terhadap penurunan tingkat kekambuhan asma pada penderita asma. Teknik pernafasan Buteyko adalah sebuah metode mengatur pola nafas yang dilakukan secara sederhana sebagai manajemen penatalaksanaan asma dengan cara bernafas melalui hidung (menghirup dan mengeluarkan udara) tanpa menggunakan mulut (mulut tertutup) yang bertujuan 


\section{Prosiding Seminar Nasional Kesehatan 2021 Lembaga Penelitian dan Pengabdian Masyarakat Universitas Muhammadiyah Pekajangan Pekalongan}

untuk mengurangi kerja pernafasan sehingga sesak nafas berkurang dengan prinsip latihan nafas dangkal Adha 2013 diambil dari Bachri, 2018)[1].

Adapun persamaan yang ditemukan pada ketiga artikel tersebut yaitu teknik pernafasan Buteyko terbukti dapat menurunkan frekuensi kekambuhan asma. Zara (2012) diambil dari Bachri (2018)[1] menyatakan terdapat pengaruh yang bermakna dalam pemberian teknik pernafasan Buteyko terhadap penurunan kekambuhan asma. Penelitian lain juga mendapatkan hasil yang sama, bahwa terapi pernafasan Buteyko efektif terhadap penurunan gejala asma pada penderita asma (Nurdiansyah, 2013 diambil dari Mashanah, dkk 2019)[6]. Teknik pernafasan Buteyko melatih cara bernafas secara efektif dan efisien dengan mengandalkan otot diafragma sebagai otot pernafasan utama dan dapat mengurangi hiperventilasi secara bertaham jika melakukan latihan secara teratur, sehingga dapat meningkatkan kadar karbondioksida didalam darah yang selanjutnya akan menjaga keseimbangan $\mathrm{pH}$ darah melalui pembentukan asam karbonat dan bikarbonat, serta mengurangi ekspirasi paksa dan penekanan pada otot dinding dada yang menyebabkan rasa sesak (Dupler 2005 diambil dari Barotoh dkk, 2014)[2]. Menurut Dupler dalam Andriyani (2012) diambil dalam Bachri (2018)[1] mengatakan teknik pernafasan buteyko juga berguna untuk mengurangi ketergantungan terhadap obat pada penderita asma karena dapat memanfaatkan teknik pernafasan dasar secara alami dan berguna untuk mengurangi gejala asma bahkan dapat mengurangi tingkat keparahan pada penderita asma.

Namun dari ketiga artikel penelitian yang telah dilakukan literature review terdapat beberapa perbedaan yaitu metode dalam ketiga jurnal penelitian ini juga berbeda pada artikel pertama menggunakan metode penelitian Pre Experimental dengan menggunakan rancangan One Group Pre and Post Test kemudian pada artikel kedua dan ketiga menggunakan metode Desain Quasy Experimental Pre and Post Test Without Control Group. Hastjarjo (2019)[3] mengatakan Desain Quasy Experimental adalah jenis desain penelitian yang memiliki penempatan unit terkecil eksperimen kedalam kelompok kontrol dan kelompok eksperimen tidak dipilih secara random. Sedangkan Pre Eksperiment merupakan rancangan penelitian yang belum dikategorikan sebagai penelitian sungguhan karena masih terdapat variabel luar yang berpengaruh terhadap terbentuknya variabel bebas. Meskipun berbeda, namun kedua desain penelitian ini dapat dipakai sebagai metode penelitian eksperimen.

Pada artikel 1, 2, dan 3 penelitian ini menggunakan teknik pengambilan sampel yang berbeda-beda. Artikel 1 menggunakan teknik sampel yaitu Accidental sampling, artikel 2 menggunakan teknik Consecutive Sampling, dan pada artikel 3 menggunakan metode non-probability sampling jenis total sampling. Adanya perbedaan teknik pengambilan sampel tersebut itu dimungkinkan karena teknik pengambilan sampel ini disesuaikan dengan tujuan dan kondisi penelitian artikel tersebut. Contohnya teknik pengambilan sampel Purposive Sampling adalah teknik pengambilan sampel dengan menentukan kriteria-kriteria tertentu yang ditentukan oleh peneliti sendiri untuk dijadikan sampel sesuai dengan kebutuhan peneliti (Juwita \& Sary, 2019)[5].

Adapun perbedaan berikutnya yang ditemukan pada artikel 1,2, dan 3 dilihat dari waktu pelaksanaan diberikan teknik pernafasan buteyko, pada artikel 1 teknik pernafasan buteyko dilakukan selama satu bulan dengan latihan setiap harinya dan 


\section{Prosiding Seminar Nasional Kesehatan 2021 Lembaga Penelitian dan Pengabdian Masyarakat Universitas Muhammadiyah Pekajangan Pekalongan}

diobservasi oleh peneliti setiap minggunya untuk mengatahui frekuensi kekambuhan asma pada responden, artikel 3 menjelaskan teknik pernafasan buteyko ini dilakukan 3 kali sehari selama 2 minggu, namun berbeda dengan artikel 2 tidak dijelaskan waktu pelaksanaan.

Perbedaan berikutnya yaitu pada artikel 1,2, dan 3 tidak ada kesamaan atau pembagian rata umur ataupun jenis kelamin artinya semua umur ataupun jenis kelamin memiliki peluang yang sama untuk mengalami kekambuhan asma. Hal ini sejalan dengan penelitian Wahyuni (2012) diambil dari Baroroh (2014)[2] tentang faktor resiko kekambuhan asma yang menyebutkan tidak ada faktor usia maupun jenis kelamin untuk mempengaruhi resiko kekambuhan asma melainkan faktor cuaca, asap rokok, gangguan emosi, infeksi saluran pernafasan dan faktor olahraga yang dapat mempengaruhi kekambuhan asma.

\section{Kesimpulan}

Dari ketiga artikel penelitian yang telah dilakukan literature review memiliki persamaan yaitu sama-sama membahas tentang pengaruh teknik pernafasan Buteyko terhadap penurunan frekuensi kekambuhan asma pada penderita asma dan ketiga artikel tersebut terbukti efektif. Sedangkan perbedaan pada ketiga artikel penelitian ini dapat dilihat dari metode penelitian, teknik pengambilan sampel yang digunakan, dan waktu pelaksanaan teknik pernafasan Buteyko. Sehingga dapat disimpulkan terdapat adanya pengaruh dilakukannya intervensi teknik pernafasan Buteyko terhadap penurunan frekuensi kekambuan asma.

\section{Referensi}

[1] Bachri, Y. (2018). Pengaruh Teknik Pernafasan Buteyko Terhadap Frekuensi Kekambuhan Asma Pada Penderita Asma Bronkhial Di UPT Puskema Wilayah Kerja Lima Kaum 1 Kabupaten Tanah Datar Tahun 2017. Menara IImu, 7(8), 174-179. Diambil dari: https://www.jurnal.umsb.ac.id/index.php/menarailmu/article/viewFile/881/792

[2] Baroroh, I., Hermansyah, \& Septiyanti. (2014). Pengaruh Teknik Pernafasan Buteyko Terhadap Penurunan Frekuensi Kekambuhan Asma Pada Pasien Penderita Asma. Jurnal Media Kesehatan, 8(2), 124-129. Diambil dari: http://jurnal.poltekkeskemenkesbengkulu.ac.id/index.php/jmk/article/view/235

[3] Hastjarjo, T, D. (2019). Rancangan Experiment-Kuasi. Buletin Psikologi, 27(2), 187-203. Diambil

dari: https://journal.ugm.ac.id/buletinpsikologi/article/view/38619

[4] Indrawati, L \& Anggiarti, G. (2021). Pengaruh Teknik Pernafasan Buteyko Terhadap Frekuensi Kekambuhan Asma Bronkhial. Jurnal Ilmu Kesehatan, 9(2), 103-109. Diambil dari: https://ejurnaladhkdr.com/index.php/jik/article/view/313

[5] Juwita, L \& Sary, I, P. (2019). Pernafasan Buteyko Bermanfaat dalam Pengontrolan Asma. Real in Nursing Journal (RNJ), 2(1), 10-20. Diambil dari: https://ojs.fdk.ac.id/index.php/nursing/index

[6] Maskhanah, Noor hidayah, Firdaus, \& Rivan. (2019). Pengaruh Teknik Pernafasan Buteyko Terhadap Kekambuhan Asma Bronkhial. Mahakam Nursing 


\section{Prosiding Seminar Nasional Kesehatan Lembaga Penelitian dan Pengabdian Masyarakat Universitas Muhammadiyah Pekajangan Pekalongan}

Jurnal, 2(6), 254-262. Diambil dari: http://ejournalperawat.poltekkeskaltim.ac.id/index.php/nursing/article/view/47

[7] Nursalam. (2013). Metodologi Penelitian IImu Keperawatan: Pendekatan Praktis. Jakarta Selatan: Salemba Medika

[8] Rab, T. (2017), Ilmu penyakit paru. Jakarta: Trans Info Media

[9] Santoso, H. (2015). Pencegahan dan Penanggulangan Plagiarisme Dalam Penulisan Karya Ilmiah Di Lingkungan Perpustakaan Perguruan Tinggi. Digital Library Universitas Negri Malang. Diambil dari: http://library.um.ac.id/images/stories/pustakawan/pdfhasan/plagiarisme.pdf

[10] Smeltzer, S.C. (2017), Keperawatan Medikal Bedah Brunner \& Suddart. Jakarta: Kedokteran EGC

[11] Setiawan. H., Windyastuti, E. (2019). Nursing Care Astma Patients In Fulfillment Of Physiological Need: Oxygenation. Nursing Study Program Of Stikes Kusuma Husada Surakarta.

http://eprints.ukh.ac.id/id/eprint/45/

[12] Triandini, E., Jayanatha, S., Indrawan, A., Putra, G., W., \& Iswara, B. (2019). Metode Systematic Literature Review untuk Identifikasi Platform dan Metode Pengembangan Sistem Informasi di Indonesia. Indonesia Journal Of Information System. 1(2), 63-77. Diambil dari: http://ojs.uajy.ac.id/index.php/IJIS/article/view/1916 